\title{
FAKTOR-FAKTOR YANG MEMPENGARUHI TINGKAT UNDERPRICING SAHAM PADA PERUSAHAAN YANG MELAKUKAN INITIAL PUBLIC OFFERING YANG TERDAFTAR DI BURSA EFEK INDONESIA
}

\author{
Mega Gunawan dan Viriany Jodin \\ Fakultas Ekonomi Universitas Tarumanagara \\ Email:virianyjodin@gmail.com
}

\begin{abstract}
The purpose of this study is to obtain empirical evidence of return on assets, debt to equity ratio, earnings per share, firm age, firm size and the percentage of stock offering to the public of the level of underpricing of shares in a company which do initial public offering in Bursa Efek Indonesia. The population in this study is all companies that do an initial public offering listed in the Bursa Efek Indonesia with period of 2007 to 2012, which amounted to 125 companies that obtained through field studies in Bursa Efek Indonesia. Samples are selected by using purposive sampling method amounted to be 66 companies. The method of analysis in this study using multiple regression analysis. Purpose to through analysis multiple regression is to prove the effect of each six variables about level of underpricing. The results of this study showed that return on assets and firm size which have a significant influence on the level of underpricing.
\end{abstract}

Key Word: return on assets, debt to equity ratio, earning per share, firm age, firm size, the percentage of stock offering to the public, underpricing

Abstrak: Tujuan penelitian ini adalah untuk mendapatkan bukti empiris return on asset, debt to equity ratio, earning per share, umur perusahaan, ukuran perusahaan dan persentase penawaran saham ke publik terhadap tingkat underpricing saham pada perusahan yang melakukan initial public offering di Bursa Efek Indonesia. Populasi dalam penelitian ini adalah perusahaan yang melakukan initial public offering yang terdaftar di Bursa Efek Indonesia dengan periode penelitian tahun 2007 sampai dengan tahun 2012, yakni berjumlah 125 perusahaan yang didapat melalui studi lapangan di Bursa Efek Indonesia. Sampel dipilih dengan menggunakan metode purposive sampling berjumlah 66 perusahaan. Metode analisis pada penelitian ini menggunakan analisis regresi berganda. Melalui anilisis regresi berganda dapat diketahui pengaruh dari masing-masing keenam variabel terhadap tingkat underpricing. Hasil penelitian ini menunjukkan bahwa variabel return on asset dan ukuran perusahaan, yang memiliki pengaruh signifikan terhadap tingkat underpricing.

Kata kunci: return on asset, debt to equity ratio, earning per share, umur perusahaan, ukuran perusahaan, perentase penawaran saham ke masyarakat, underpricing

\section{PENDAHULUAN}

Penelitian ini bertujuan untuk menguji seberapa besar tingkat underpricing yang terjadi di Indonesia pada saat melakukan penawaran saham ke publik atau disebut dengan Initial Public Offering. Initial public offering adalah salah satu cara perusahaan untuk memperoleh dana atau pemenuhan dana. 
Pemenuhan modal atau dana merupakan kebutuhan yang sangat penting bagi sebuah perusahaan. Perkembangan zaman yang diiringi dengan perkembangan teknologi dan komunikasi, dewasa ini telah menciptakan iklim persaingan yang ketat. Berbagai perusahaan selalu berusaha untuk mempertahankan bisnisnya dalam kompetitif persaingan, salah satunya dengan cara melakukan ekspansi guna memperluas usahanya agar sejalan dengan perkembangan ekonomi yang terus maju. Kebutuhan penambahan modal akan semakin besar seiring dengan perkembangan perusahaan. Hal ini akan mendorong manajemen untuk memilih salah satu dari alternatif-alternatif pembiayaan, baik yang berasal dari dalam yakni laba ditahan maupun yang berasal dari luar perusahaan melalui pinjaman modal atau penambahan jumlah kepemilikan saham dengan penerbitan saham baru. Penerbitan saham baru merupakan salah satu upaya yang dapat ditempuh oleh perusahaan dengan cara menjual hak atas kepemilikannya. Apabila manajemen memutuskan untuk menambah jumlah kepemilikan saham maka dapat dilakukan dengan berbagai cara, antara lain menjual kepada pemegang saham yang sudah ada, menjual kepada karyawan dengan cara ESOP (Employee Stock Ownership Plan), menambah saham melalui dividen yang tidak dibagi atau menawarkan kepada masyarakat umum atau publik melalui penawaran saham di pasar modal. Kegiatan perusahaan untuk menjual sahamnya kepada publik melalui pasar perdana untuk pertama kalinya disebut sebagai penawaran umum perdana atau yang dikenal sebagai initial public offering. Initial public offering merupakan alternatif pendanaan dengan cara meningkatkan ekuitas kepemilikan dengan menawarkan efeknya (saham, obligasi, surat-surat berharga lainnya) kepada masyarakat umum atau publik.

Menurut Kristiantari (2012), harga saham yang akan dijual perusahaan pada pasar perdana ditentukan oleh kesepakatan antara calon emiten dengan underwriter, sedangkan harga saham yang dijual pada pasar sekunder ditentukan oleh mekanisme pasar, yaitu permintaan dan penawaran atas saham itu sendiri. Underwriter dalam hal ini memiliki informasi lebih baik mengenai permintaan terhadap saham-saham emiten, dibanding emiten itu sendiri (asymmetry information). Underwriter akan memanfaatkan informasi yang dimilikinya untuk memperoleh kesepakatan yang optimal dengan emiten, yaitu memperkecil risiko keharusannya dengan menekan harga saham menjadi lebih murah. Demikian akan terjadi underpricing, artinya bahwa harga saham pada saat penawaran perdana lebih rendah dibanding dengan harga saham di pasar sekunder. Kondisi sebaliknya jika harga saham saat penawaran perdana lebih tinggi dibanding harga saham di pasar sekunder, maka dapat disebut dengan istilah overpricing.

Retnowati berpendapat (2013) kondisi underpricing merugikan untuk perusahaan yang melakukan go public, karena dana yang diperoleh dari publik tidak maksimum. Sebaliknya jika terjadi overpricing, maka investor akan rugi, karena mereka tidak menerima initial return (return awal). Initial return adalah keuntungan yang didapat pemegang saham akibat underpricing. Fenomena underpricing terjadi di berbagai pasar modal di seluruh dunia karena adanya asimetri informasi. Guna mengurangi adanya asimetri informasi maka dilakukanlah penerbitan prospektus oleh perusahaan yang akan melakukan initial public offering. Informasi yang tercantum dalam prospektus terdiri dari informasi yang sifatnya keuangan dan non keuangan. Informasi yang dimuat dalam prospektus akan membantu investor dalam mempertimbangkan dan membuat keputusan investasi. Penelitian yang akan dilakukan merupakan penelitian yang melibatkan beberapa variable penelitian antara variable keuangan (return on asset, debt to equity ratio dan earning per share) dan non keuangan (umur perusahaan (age), ukuran perusahaan (size) 
dan persentase penawaran saham ke publik) terhadap tingkat underpricing saham yang terdaftar di Bursa Efek Indonesia.

\section{KAJAIN TEORI}

Pasar Modal. Secara umum pasar modal merupakan tempat bertemunya permintaan dan penawaran atas instrumen keuangan jangka panjang, yang umumnya lebih dari satu tahun. Menurut Darmadji dan Fakhruddin (2006) pasar modal merupakan sarana bagi perusahaan untuk memenuhi kebutuhan pendanaan dan memfasilitasi kebutuhan masyarakat untuk berinvestasi pada beragam instrumen finansial seperti saham, obligasi, reksa dana dan lain-lain.

Menurut Sunariyah (2006) pasar modal di Indonesia dibagi menjadi empat jenis kategori. Pertama, pasar perdana (primary market) adalah tempat penawaran saham dari perusahaan yang menerbitkan saham (emiten) kepada pemodal selama waktu yang ditetapkan sebelum saham tersebut diperdagangkan di pasar sekunder. Kedua, pasar sekunder (secondary market) didefinisikan sebagai perdagangan saham setelah melewati masa penawaran pada pasar perdana. Jadi, pasar sekunder sebagai tempat di mana saham dan sekuritas lain diperjualbelikan secara luas, setelah melalui masa penjualan di pasar perdana. Harga saham di pasar sekunder ditentukan oleh permintaan dan penawaran antara pembeli dan penjual. Ketiga, pasar ketiga (third market) merupakan tempat perdagangan saham atau sekuritas lain di luar bursa (over the counter market). Keempat, pasar keempat (fourth market) merupakan bentuk perdagangan efek antar pemodal atau dengan kata lain pengalihan saham dari satu pemegang saham ke pemegang saham lainnya tanpa melalui perantara pedagang efek.

Initial Public Offering. Initial Public Offering (IPO) merupakan kegiatan penawaran efek (saham atau obligasi) suatu perusahaan kepada masyarakat umum untuk pertama kalinya. Saat perusahaan belum menjual saham-sahamnya kepada publik, maka saham perusahaan dimiliki oleh para pemilik dan manajer-manajernya. Perusahaan yang telah melakukan penawaran saham perdana telah merubah status perusahaannya menjadi perusahaan publik. Retnowati (2013) mengatakan, berbagai alasan perusahaan melakukan initial public offering antara lain untuk meningkatkan modal, mempermudah usaha pembelian perusahaan lain dan memungkinkan manajemen maupun masyarakat mengetahui nilai perusahaan.

Menurut Saunders dan Cornett (2003),

"Primary market financial instruments include issues of equity by firms initially going public (e.g. allowing their equity shares-to be publicly traded on stocks markets for the first time). These first-time issues are usually referred to as initially public offerings (IPOs)."

Menurut Darmadji dan Fakhruddin (2006) proses initial public offering atau go public dinyatakan sejak masa persiapan hingga listing di bursa efek, dikelompokkan menjadi empat tahap. Pertama, tahap persiapan merupakan tahap awal dalam rangka persiapan segala sesuatu yang berkaitan dengan proses penawaran umum. Pada tahap yang lebih awal perusahaan yang akan menerbitkan saham terlebih dahulu melakukan Rapat Umum Pemegang Saham (RUPS) untuk meminta persetujuan para pemegang saham dalam rangka penawaran umum. Jika telah mendapat persetujuan, selanjutnya emiten melakukan penunjukkan penjamin emisi, lembaga dan profesi penunjang pasar modal 
seperti akuntan publik, konsultan hukum, penilai dan notaris. Kedua, tahap pengajuan pernyataan. Pada tahap ini, dilakukan pengumpulan dokumen-dokumen pendukung dan calon emiten menyampaikan pendaftaran kepada Badan Pengawas Pasar Modal, BAPEPAM untuk menyatakan pernyataan pendaftaran menjadi efektif. Ketiga, tahap penawaran saham merupakan tahapan utama karena pada waktu inilah emiten menawarkan saham kepada masyarakat investor. Investor dapat membeli saham tersebut melalui agen-agen penjual yang telah ditunjuk. Keempat, tahap pencatatan saham di Bursa Efek. Tahap Selanjutnya, setelah selesai penjualan saham di pasar perdana, selanjutnya saham tersebut dicatatkan di Bursa Efek. Salah satu syarat yang ditetapkan pengawas pasar modal untuk perusahaan yang akan melakukan initial public offering (penawaran saham perdana) di pasar modal adalah dokumen prospektus. Darmadji dan Fakhruddin (2006) mengemukakan "Prospektus adalah setiap informasi tertulis sehubungan dengan penawaran umum dengan tujuan agar pihak lain membeli efek."

Underpricing. Menurut Khomsiyah (2005) harga saham ditentukan berdasarkan kesepakatan antara emiten dan penjamin emisi, disinilah akan timbul fenomena underpricing karena ada perbedaan informasi yang dimiliki oleh pihak-pihak yang terlibat dalam penawaran perdana yaitu emiten, penjamin emisi dan investor. Sebelum saham diperdagangkan di pasar sekunder, saham akan terlebih dahulu dijual di pasar perdana.

Menurut Yasa dalam Yustisia dan Roza (2012), underpricing merupakan selisih positif harga saham di pasar sekunder dengan harga saham di pasar primer saat penawaran perdana. Artinya harga saham di pasar sekunder akan lebih tinggi dibandingkan dengan harga saham pada saat penawaran perdana. Selisih harga tersebut disebut dengan istiliah initial return (IR). Caster dan Manaster menyatakan dalam Arman (2012) underpricing terjadi akibat ketidakpastian harga saham pada pasar perdana. Fenomena ini disebabkan karena adanya mispriced di pasar perdana akibat ketidakseimbangan informasi antara pihak underwriter dengan pihak emiten. Terdapat dua sisi pendapat yang saling bertentangan yakni emiten sebagai pihak yang membutuhkan dana, pasti menginginkan harga saham perdana yang tinggi, di sisi lain underwriter sebagai penjamin menginginkan harga yang rendah demi mengurangi risiko yang ditanggungnya.

Return on Asset. Profitabilitas suatu perusahaan merupakan perbandingan antara laba dengan aktiva atau dengan modal yang menghasilkan laba tersebut. Salah satu rasio profitabilitas adalah return on asset. Return on asset digunakan untuk mengukur efektivitas perusahaan dalam menghasilkan keuntungan dengan cara memanfaatkan aktiva yang dimilikinya. Nilai profitabilitas yang semakin tinggi akan menunjukkan perusahaan mampu menghasilkan laba di masa akan datang dan laba merupakan informasi penting bagi investor sebagai pertimbangan investor dalam menanamkan modalnya.

Witjaksono (2012) mengatakan profitabilitas yang diukur dengan return on asset merupakan salah satu potensi yang dimiliki oleh perusahaan dalam menentukan harga perdana (offering price) saham. Semakin tinggi tingkat profitabilitas perusahaan menunjukkan tingginya kemampuan perusahaan untuk menghasilkan keuntungan atau laba sehingga hal tersebut dapat dilihat investor sebagai perusahaan yang menguntungkan. Hal ini dapat mengurangi ketidakpastian melakukan initial public offering dalam menentukan harga saham yang wajar sehingga dapat menurunkan tingkat underpricing. Dapat disimpulkan semakin tinggi rasio return on asset, maka semakin kecil tingkat 
underpricing, dan sebaliknya semakin rendah return on asset, maka semakin besar kemungkinan tingkat underpricing yang akan terjadi.

Debt to Equity Ratio. Debt to equity ratio adalah rasio yang membandingkan hutang perusahaan dengan total ekuitas. Debt to equity ratio merupakan financial leverage yang dipertimbangkan sebagai variabel keuangan karena secara teoritis menunjukkan risiko suatu perusahaan sehingga berdampak pada ketidakpastian harga saham. Salah satu parameter digunakan untuk mengukur leverage adalah debt to equity ratio. Gibson menyatakan (2013) "Debt to ratio is another coumputation that determines the entity's long-term debt paying ability. This computation compares the total debt with the total shareholder's equity."

Witjaksono (2012) menyatakan besarnya debt to equity ratio perusahaan menunjukkan semakin besarnya risiko finansial atau risiko kegagalan perusahaan untuk mengembalikan pinjamannya sehingga dapat memengaruhi penetapan harga saham yang wajar pada saat penawaran perdana. Debt to equity ratio yang tinggi dapat menyebabkan penetapan harga saham di pasar perdana cenderung underpriced karena akan berpengaruh tinggi terhadap ketidakpastian return yang akan diterima investor atas investasinya. Dapat disimpulkan, semakin tinggi debt to equity ratio perusahaan semakin besar pula tingkat underpricing.

Earning per Share. Earning per share merupakan salah satu bahan pertimbangan para calon investor dalam memilah perusahaan yang mana yang akan investor tanamkan modalnya. Pada dasarnya rasio ini merupakan rasio yang sangat disukai oleh manajemen perusahaan dan calon investor dalam hal mengukur jumlah rupiah yang diperoleh untuk setiap lembar saham. Para calon investor cenderung tertarik dengan earning per share yang besar karena earning per share merupakan salah satu faktor yang dapat mencerminkan keberhasilan perusahaan dalam bisnisnya.

Penjelasan mengenai earning per share menurut IAI (2009: 56.1) dalam SAK adalah sebagai berikut:

"Laba Per Saham (LPS) adalah data yang banyak digunakan sebagai alat analisis keuangan. LPS dengan ringkas menyajikan kinerja perusahaan dikaitkan dengan saham beredar, LPS yang dikaitkan dengan harga pasar saham (price earning ratio) bisa memberikan gambaran tentang kinerja perusahaan dibanding dengan uang yang ditanam pemilik perusahaan."

Beberapa pengertian di atas dapat ditarik kesimpulan bahwa earning per share merupakan laba per saham dari saham yang beredar selama periode tertentu guna mewakili sejumlah rupiah yang diperoleh atas kepentingan saham beredar dan digunakan sebagai alat analisis keuangan dengan menunjukkan pendapatan perusahaan berdasarkan per lembar saham. Earning per share yang tinggi, akan membuat semakin banyak investor yang mau membeli saham tersebut sehingga menyebabkan harga saham tinggi dalam hal ini dapat berpengaruh terhadap underpricing.

Umur Perusahaan (Age). Umur perusahaan dapat menunjukkan kemampuan perusahaan untuk bertahan hidup dan banyaknya informasi yang bisa diserap oleh publik. Menurut Christy et al., (1996) dalam Indirawati (2005) menyatakan umur perusahaan menunjukkan kondisi perusahaan yang tetap bertahan dan menjadi bukti bahwa perusahaan mampu bersaing dan dapat mengambil kesempatan bisnis yang ada dalam perekonomian. Perusahaan yang beroperasi lebih lama mempunyai kemampuan yang lebih besar untuk 
menyediakan informasi. Dengan demikian akan mengurangi adanya informasi asimetri dan memperkecil ketidakpastian pasar yang pada akhirnya akan menurunkan tingkat underpricing saham.

Ukuran Perusahaan (Size). Perusahaan yang berskala besar umumnya lebih dikenal oleh masyarakat dibandingkan dengan perusahaan berskala kecil. Terdapat beberapa parameter yang digunakan untuk menentukan ukuran suatu perusahaan, antara lain banyaknya jumlah karyawan yang digunakan dalam perusahaan, total aset, total penjualan yang dicapai oleh perusahaan dalam suatu periode serta kapitalisasi pasar. Suyatmin dan Sujadi, (2006) menyatakan dalam Astuti dan Syahyunan, (2013) untuk mengukur besarnya skala atau ukuran dari suatu perusahaan dapat dilihat dari total aktiva sehingga informasi yang didapat investor pada perusahaan yang berskala besar menunjukkan semakin tinggi pula dan tingkat ketidakpastian di masa yang akan datang semakin rendah. Guna untuk mengukur ukuran perusahaan total aset menjadi proksi dari ukuran perusahaan.

Yolana dan Martani (2005) dalam Witjaksono (2012) mengungkapkan semakin besar ukuran perusahaan maka akan mengurangi penetapan harga yang cenderung underpriced karena memiliki risiko ketidakpastian yang lebih rendah dibandingkan dengan perusahaan berukuran kecil sehingga semakin rendah return yang diharapkan sebagai kompensasi atas risiko tersebut.

Persentase Penawaran Saham. Leland dan Pyle (1977) dalam (Indirawati, 2005) menunjukkan persentase kepemilikan yang ditahan oleh pemilik menunjukkan adanya private information dari pemilik lama kepada investor. Informasi tingkat kepemilikan saham oleh pemilik atau penawaran saham kepada masyarakat akan digunakan oleh investor sebagai pertanda bahwa prospek perusahaanya baik. Semakin besar tingkat kepemilikan yang ditahan atau semakin kecil persentase saham yang ditawarkan, akan memperkecil tingkat ketidakpastian di masa yang akan datang. Jadi semakin kecil persentase saham yang ditawarkan ke publik maka tingkat underpricing semakin rendah. Sebaliknya, jika penawaran saham ke publik cenderung besar maka tingkat underpricing saham akan menunjukkan sinyal yang akan semakin tinggi pula.

Penelitian Terdahulu dan Pengembangan Hipotesis. Eka Retnowati (2013) dalam penelitiannya yang berjudul Penyebab Underpricing Pada Penawaran Saham Perdana Di Indonesia menguraikan beberapa variabel yang memengaruhi underpricing. Variabel tersebut antaranya adalah debt to equity ratio, return on asset, earning per share, umur perusahaan, ukuran perusahaan dan persentase penawaran saham ke publik. Dari 55 perusahaan yang diambil sebagai sampel yang diteliti pada periode tahun 2008-2011, variabel yang memiliki pengaruh signifikan terhadap tingkat underpricing saham adalah earning per share, ukuran perusahaan dan persentase kepemilikan saham oleh publik. Sedangkan variabel yang debt to equity ratio, return on asset, dan umur perusahaan tidak memiliki pengaruh yang signifikan terhadap tingkat underpricing saham.

Roskarina Setianingrum dan K. Tjilik Suwito (2008), menyatakan bahwa hasil penelitian yang diperoleh reputasi underwriter dan financial leverage berpengaruh signifikan terhadap tingkat underpricing sedangkan variabel return on asset tidak berpengaruh signifikan terhadap tingkat underpricing.

Asih Yuli Astuti dan Syahyunan (2012), dalam penelitiannya memperoleh hasil bahwa hanya reputasi underwriter yang berpengaruh negatif dan signifikan terhadap underpricing sedangkan profitabilitas, leverage, besaran perusahaan (size), earning per 
share, ukuran penawaran saham (proceeds), umur perusahaan, reputasi auditor, inflasi dan suku bunga berpengaruh tidak signifikan terhadap underpricing.

Agus Arman (2012), penelitannya memperoleh hasil yang membuktikan bahwa umur dan ukuran perusahaan, reputasi underwriter, return on equity memiliki pengaruh signifikan terhadap underpricing saham. Natali Yustisia dan Mailana Roza (2012), menunjukan reputasi penjamin emisi berpengaruh signifikan terhadap tingkat underpricing, sedangkan reputasi auditor, profitabilitas, skala perusahaan, dan persentase penawaran saham public tidak memiliki pengaruh yang signifikan.

Berdasarkan uraian di atas maka dapat disusun enam hipotesis, yakni adalah sebagai berikut;

$\mathrm{Ha}_{1}$ : Return on asset memiliki pengaruh yang signifikan terhadap tingkat underpricing saham.

$\mathrm{Ha}_{2}$ : Debt to equity ratio memiliki pengaruh yang signifikan terhadap tingkat underpricing saham.

$\mathrm{Ha}_{3}$ : Earning per share memiliki pengaruh yang signifikan terhadap tingkat underpricing saham.

$\mathrm{Ha}_{4}$ : Umur perusahaan memiliki pengaruh yang signifikan terhadap tingkat underpricing saham.

Ha5: Ukuran perusahaan memiliki pengaruh yang signifikan terhadap tingkat underpricing saham.

$\mathrm{Ha}_{6}$ : Persentase penawaran saham ke publik memiliki pengaruh yang signifikan terhadap tingkat underpricing saham.

\section{METODE}

Populasi dan Sampel. Populasi yang digunakan untuk analisis dalam penelitian adalah perusahaan yang melakukan initial public offering dan mencatatkan sahamnya di Bursa Efek Indonesia selama periode 2007-2012. Teknik penarikan sampel yang digunakan adalah purposive sampling. Perusahaan yang akan dijadikan sebagai sampel adalah perusahaan yang memiliki kriteria sebagai berikut (1) perusahaan yang melakukan kegiatan initial public offering dan terdaftar di Bursa Efek Indonesia dalam periode 2007-2012 (2) perusahaan yang mengalami underpricing (3) perusahaan yang bukan termasuk jenis usaha dalam bidang keuangan, (4) perusahaan yang tidak mengalami relisting atau delisting, (5) perusahaan yang menggunakan mata uang rupiah, (6) perusahaan yang memiliki laba positif pada satu tahun sebelum melakukan initial public offering, (7) perusahaan yang memiliki prospektus atau laporan dan data keuangan yang lengkap (sesuai dengan data yang diperlukan dalam variabel penelitian) yang menjadi sumber data yang akan digunakan untuk penelitian.

Pengumpulan Data. Obyek penelitian yang digunakan dalam penelitian ini adalah, return on asset $\left(\mathrm{X}_{1}\right)$, debt to equity ratio $\left(\mathrm{X}_{2}\right)$, earning per share $\left(\mathrm{X}_{3}\right)$, umur perusahaan, $\left(\mathrm{X}_{4}\right)$, ukuran perusahaan $\left(\mathrm{X}_{5}\right)$, persentase penawaran saham ke publik $\left(\mathrm{X}_{6}\right)$. Underpricing sebagai variabel (Y) dalam penelitian yang dilakukan pada perusahaan yang melakukan Initial Public Offering periode 2007-2012 di Bursa Efek Indonesia. Data sekunder mengenai return on asset, debt to equity ratio, ukuran perusahaan, persentase penawaran saham ke publik didapat melalui laporan prospektus yang didapat dari pojok Bursa 
Indonesia dan perpustakaan online I-Camel Bursa Indonesia, sedangkan umur perusahaan didapat dari profile perusahaan yang ada dalam Fact Book pada website IDX.

Pengolahan Data. Variabel terikat dalam penelitian ini adalah tingkat underpricing saham pada saat IPO. Underpricing merupakan selisih positif antara harga di pasar sekunder dibandingkan dengan harga saham di pasar primer, yang mana harga jual saham di pasar primer lebih rendah dibanding dengan harga saham di pasar sekunder.

Variabel bebas dalam penelitian ini terdiri dari (1) Return on asset yang diukur dengan membagi net income dengan total assets sesuai dengan penelitian Roskarina dan Tjilik (2008), (2) Debt to equity ratio yang diukur dengan membagi total debt dengan total asset sesuai penelitian Retnowati (2013), (3) Earning per share diukur dengan membagi net income after tax dengan outstanding shares sesuai dengan penelitian yang dilakukan Asih dan Syahyunan (2012), (4) Umur perusahaan diukur dengan mengurangi tahun melakukan IPO dengan tahun perusahaan berdiri berdasarkan penelitian yang dilakukan berdasarkan Trisnawati (1998), Nurhidayati (1998) dalam Retnowati (2013), (5) Ukuran perusahaan diukur dengan melihat total aset perusahaan pada saat melakukan IPO di Bursa Efek Indonesia sesuai dengan penelitian yang dilakukan Agus (2012), (6) Persentase penawaran saham ke publik dapat diketahui dengan cara membandingkan selisih antara total saham beredar dan jumlah saham yang ditahan pemilik lama dibagi dengan jumlah saham yang beredar. Sedangkan variabel terikat yakni underpricing dapat diperoleh dari selisih antara harga penutup saham di pasar sekunder dengan harga saham pada saat IPO dibagi dengan harga saham pada saat IPO sesuai dengan penelitian yang dilakukan Handayani dan Shaferi (2011).

Data yang telah dikumpulkan akan diolah dengan melalui beberapa tahapan, antara lain analisis statistik deskriptif, pengujian asumsi klasik dan pengujian hipotesis melalui regresi berganda. Analisis deskriptif dilakukan guna dapat menghasilkan parameter yang baik. Suatu model regresi berganda yang baik dan layak dipakai untuk memprediksi variabel terikat berdasarkan pada masukan variabel bebas adalah model regresi berganda yang memenuhi asumsi normalitas serta tidak terjadi gejala multikolinearitas, autokolerasi, dan heteroskedastisitas. Kondisi tersebut mengartikan bahwa data yang akan digunakan harus diuji kelayakannya terlebih dahulu dengan melakukan uji asumsi, jika telah lolos uji asumsi dapat dilanjutkan ke pengujian hipotesis. Pengujian hipotesis menggunakan analisis regresi berganda. Menurut Ghozali (2011) dalam analisis regresi, selain mengukur kekuatan hubungan antara dua variabel atau lebih, juga menunjukkan arah hubungan antara variabel dependen dengan variabel independen. Persamaan regresi berganda yang akan dibentuk pada penelitian ini adalah:

$$
Y=a+b_{1} X_{1}+b_{2} X_{2}+b_{3} X_{3}+b_{4} X_{4}+b_{5} X_{5}+b_{6} X_{6}+e
$$

Keterangan Y = Tingkat Underpricing; a = Nilai Intercept atau konstanta; b1-6 = koefisien regresi parsial yaitu besarnya perubahan Y apabila X berubah satu satuan; X1= Return on asset $(\mathrm{ROA}) ; \mathrm{X} 2=$ Debt to equity ratio $(\mathrm{DER}) ; \mathrm{X} 3=$ Earning per share (EPS); X4= Umur perusahaan $($ Age $) ; \mathrm{X} 5=$ Ukuran perusahaan $($ Size $) ; \mathrm{X} 6=$ Persentase penawaran saham ke publik; e $=$ Error.

Teknik pengolahan data ini menggunakan software statistik, yaitu SPSS (Statistical Product and Service Solution)19.00. 


\section{HASIL DAN PEMBAHASAN}

Pemilihan Sampel. Populasi dalam penelitian ini adalah seluruh perusahaan yang melakukan IPO selama periode 2007-2012 dan terdaftar di Bursa Efek Indonesia. Populasi yang diperoleh adalah sejumlah 125 perusahaan, namun dari populasi tersebut terdapat 50 perusahaan yang tidak sesuai kriteria, dan 9 perusahaan yang merupakan data outlier sehingga sampel penelitan yang didapat berjumlah 66 perusahaan. Berikut adalah pemaparan seleksi pemilihan sampel dalam penelitian.

Tabel 1. Proses Seleksi Sampel Penelitian

\begin{tabular}{lc}
\hline \multicolumn{1}{c}{ Kriteria } & Jumlah Perusahaan \\
\hline $\begin{array}{l}\text { Perusahaan yang melakukan initial public offering } \\
\text { periode 2007-2012 }\end{array}$ & 125 \\
$\begin{array}{l}\text { Perusahaan yang tidak mengalami underpricing pada } \\
\text { hari pertama saham di pasar sekunder }\end{array}$ & $(17)$ \\
$\begin{array}{l}\text { Perusahaan yang termasuk dalam kategori } \\
\text { perusahaan keuangan }\end{array}$ & $(13)$ \\
Perusahaan yang mengalami relisting atau delisting & \\
$\begin{array}{l}\text { Perusahaan yang tidak menggunakan rupiah } \\
\text { Perusahaan yang memiliki laba negatif pada satu }\end{array}$ & $(4)$ \\
tahun sebelum melakukan initial public offering & \\
Perusahaan yang tidak memiliki laporan dan data \\
keuangan yang tidak lengkap
\end{tabular}

Statistik Deskrptif. Sebelum membahas lebih lanjut mengenai pengujian asumsi klasik dan analisis regresi berganda, dalam bagian analisis dan pembahasan ini akan diberikan gambaran atau deskripsi terlebih dahulu mengenai data yang dikumpulkan. Pengujian statistik deskriptif menggambarkan data sampel yang digunakan dalam penelitan, sehingga dapat diketahui nilai maksimum dan minimum, nilai rata-rata (mean) dan standar deviasi dari masing-masing variabel.

Tabel 2. Hasil Statistik Deskripitif

\begin{tabular}{lrrrrr}
\hline \multicolumn{7}{c}{ Descriptive Statistics } & & \\
\hline & $\mathrm{N}$ & \multicolumn{1}{c}{ Minimum } & Maximum & \multicolumn{1}{c}{ Mean } & \multicolumn{1}{c}{ Std. Deviation } \\
\hline ROA & 66 & .0001 & .2463 & .059001 & .0559162 \\
DER & 66 & .0335 & 7.2487 & 1.739789 & 1.5079453 \\
EPS & 66 & .01 & 24477.00 & 760.0764 & 3392.30575 \\
Umur Perusahaan & 66 & 2 & 51 & 16.24 & 11.263 \\
Ukuran Perusahaan & 66 & 22185375560 & $1 . \mathrm{E} 13$ & $1.55 \mathrm{E} 12$ & $1.861 \mathrm{E} 12$ \\
Penawaran Saham ke & 66 & .1000 & .4900 & .254730 & .1041409 \\
Publik & & & & & \\
Initial Return & 66 & .0132 & 1.0612 & .333808 & .2648221 \\
Valid N (listwise) & 66 & & & & \\
\hline
\end{tabular}


Berdasarkan hasil analisis statistik deskriptif pada tabel 3 memberikan gambaran umum mengenai data dan karakteristik sampel yang digunakan di dalam penelitian. Pada tabel 3 nilai $\mathrm{N}$ menunjukkan banyaknya jumlah sampel data yang valid dan digunakan dalam penelitan ini, yakni 66 sampel data.

Diketahui dari jumlah 66 perusahaan yang diambil sebagai sampel, dapat dilihat bahwa diperoleh hasil return on asset $\left(\mathrm{X}_{1}\right)$ dengan nilai maksimal sebesar 0,2463 yang dimiliki oleh Provident Agro, Tbk dan nilai minimum sebesar 0,0001 yang dimilki oleh Nirvana Developments. Nilai rata-rata dari variabel $\left(\mathrm{X}_{1}\right)$ adalah 0,059001 dan standar deviasi 0,0559162. Dari jumlah 66 perusahaan yang diambil sebagai sampel, dapat dilihat bahwa diperoleh debt to equity ratio $\left(\mathrm{X}_{2}\right)$ dengan nilai maksimal sebesar 7,2487 yang dimiliki oleh Waskita Karya Persero Tbk, dan nilai minimum sebesar 0,0335 yang dimiliki oleh Benakat Petroleum Energy Tbk.

Nilai deskriptif yang dimiliki oleh earning per share dari 66 perusahaan yang diambil sebagai sampel, adalah dapat dilihat sebagai berikut earning per share $\left(\mathrm{X}_{3}\right)$ memiliki nilai maksimal sebesar 24477,00 dimiliki oleh Bukit Uluwatu Villa Tbk dan nilai minimum sebesar 0,01 yang dimiliki oleh Wijaya Karya Tbk. Nilai rata-rata dari variabel $\left(\mathrm{X}_{3}\right)$ adalah 760,0764 dan standar deviasi 3392,30575.

Nilai deskriptif selanjutnya ialah umur perusahaan $\left(\mathrm{X}_{4}\right)$ dari 66 perusahaan yang diambil sebagai sampel, terdapat nilai maksimum sebesar 51 yang dimiliki oleh Waskita Karya Persero Tbk dan nilai minimum sebesar 2 yang dimiliki oleh Sarana Menara Nusantara Tbk dan Inovisi Infracom Tbk. Nilai rata-rata yang ada sebesar 16,24 dan deviasi standar sebesar 11,263.

Diteruskan pada variabel $\left(\mathrm{X}_{5}\right)$ yaitu ukuran perusahaan, dari 66 data sampel perusahaan mendapatkan nilai maksimum dari variabel ini sebesar 1,E13 yang dimiliki oleh perusahaan Jasa Marga, Tbk dan nilai minimum sebesar 22185375560 yang dimiliki oleh perusahaan Skybee Tbk. Nilai rata-rata yang ada dalam variabel $\left(\mathrm{X}_{5}\right)$ adalah sebesar 1,55E12 dan nilai standar deviasi yang dimiliki 1,861E12.

Variabel terakhir yang dianalisis dalam penelitian deskriptif ini adalah persentase penawaran saham ke publik $\left(\mathrm{X}_{6}\right)$. Nilai maksimum dari variabel ini sebesar 0,4900 yang dimiliki oleh perusahaan Express Trasindo Utama Tbk dan nilai minimum sebesar 0,1000 yang dimiliki oleh perusahaan Bumi Serpong Damai Tbk dan Elang Mahkota Teknologi Tbk. Nilai rata-rata yang ada dalam variabel ini adalah sebesar 0,254730 dan nilai standar deviasi yang dimiliki 0,1041409.

Pada variabel dependen yakni tingkat underpricing (initial return) (Y), dapat diketahui nilai maksimum yang dimilki adalah sebesar 1,0612 yang dimiliki oleh Panorama Transportasi Tbk dan 0,0132 nilai minimum yang dimiliki oleh Sky Vision Tbk. Nilai rata-rata yang diperoleh dalam variabel tingkat underpricing (initial return) adalah sebesar 0,333808 dan standar deviasi sebesar 0,2648221.

Hasil Pengujian Asumsi Klasik. Uji Normalitas. Ghozali (2011) menyatakan model regresi yang baik adalah distribusi data normal dan mendekati normal. Uji normalitas dilakukan dengan One Kolmogorov-Smirnov test. Output dari pengujian ini akan menampilkan nilai asymp. Sig ( 2 tailed), jika nilai tersebut $>0.05$ maka data residual terdistribusi normal. Kondisi sebaliknya jika nilai asymp. Sig (2 tailed $)<0,05$ maka data tidak terdistribusi secara normal. Dalam hasil pengolahan data pada Tabel 4 One Sample Kolmogorov Smirnov Test menunjukkan nilai 0,852 dengan asymp.sig (2-tailed) sebesar 
0,462 yang artinya nilai tersebut lebih besar dari 0,05 sehingga dapat disimpulkan bahwa data terdistribusi secara normal.

Tabel 4. Hasil Uji Normalitas

One-Sample Kolmogorov-Smirnov Test

\begin{tabular}{llr}
\hline & & $\begin{array}{c}\text { Unstandardize } \\
\text { d Residual }\end{array}$ \\
\hline $\mathrm{N}$ & & 66 \\
Normal Parameters & Mean & .0000000 \\
& Std. Deviation & .23169878 \\
Most Extreme & Absolute & .105 \\
Differences & Positive & .105 \\
& Negative & -.064 \\
Kolmogorov-Smirnov Z & & .852 \\
Asymp. Sig. (2-tailed) & & .462 \\
\hline
\end{tabular}

a. Test distribution is Normal.

b. Calculated from data.

\section{Uji Multikolinearitas}

Tabel 5. Hasil Uji Multikolinearitas

\begin{tabular}{llrr}
\multicolumn{4}{c}{ Coefficients $^{\mathbf{a}}$} \\
\cline { 3 - 4 } Model & & \multicolumn{2}{c}{ Collinearity Statistics } \\
\cline { 3 - 4 } 1 & ROA & .914 & 1.095 \\
& DER & .722 & 1.386 \\
& EPS & .957 & 1.045 \\
& Umur Perusahaan & .848 & 1.179 \\
& Ukuran Perusahaan & .775 & 1.291 \\
& Penawaran Saham ke & .848 & 1.179 \\
& Publik & & \\
\hline
\end{tabular}

a. Dependent Variable: Initial Return

Pengujian multikolinearitas dilakukan guna menguji apakah pada model regresi ditemukan adanya korelasi antar variabel bebas. Model regresi yang baik seharusnya tidak korelasi tinggi di antara variabel bebas. Menurut Ghozali (2011), untuk mendeteksi ada atau tidaknya multikolinearitas dalam model regresi dapat dilihat dari nilai tolerance dan variance inflation factor (VIF). Nilai cutoff umum yang dipakai untuk menunjukkan adanya gejala multikolinearitas adalah nilai tolerance $\leq 0,10$ atau sama dengan nilai VIF $\geq$ 10. Kondisi sebaliknya jika tolerance $>0.10$ dan VIF $<10$ maka data yang dipakai terbebas dari multikolinearitas. Tabel 4.5. menunjukkan nilai tolerance return on asset sebesar 0,914 dan nilai VIF sebesar 1,095. Nilai tolerance debt to equity ratio sebesar 0,722 dan nilai VIF sebesar 1,386. Nilai tolerance earning per share 0,957 dan nilai VIF sebesar 1,045. Nilai tolerance umur perusahaan 0,848 dan nilai VIF sebesar 1,179 . Nilai tolerance ukuran perusahaan 0,775 dan nilai VIF sebesar 1,291 . Nilai penawaran saham ke publik 0,848 dan nilai VIF sebesar 1,179. Interpretasi di atas menunjukkan bahwa 
keseluruhan variabel bebas memiliki tolerance lebih besar dari 0,1 (tolerance $>0,01)$ dan VIF kurang dari 10 (VIF < 10). Uraian tersebut menyatakan bahwa tidak ada masalah multikolinearitas di antara variabel bebas dalam model regresi sehingga baik dan layak untuk digunakan untuk penelitian.

Uji Autokolerasi. Pengujian autokolerasi bertujuan untuk menguji apakah dalam sebuah model regresi terdapat korelasi antar kesalahan pengganggu pada periode $\mathrm{t}$ dengan kesalahan pada periode t-1 (sebelumnya). Menurut Ghozali (2011), pengujian dilakukan untuk mendeteksi apakah terjadi autokolerasi dalam model yang telah terbentuk, dengan menggunakan pengujian statistik Durbin Watson (DW). Model regresi terbebas dari autokolerasi, jika Durbin Watson (DW) dengan syarat du < DW < 4-du. Artinya nilai DW harus berada diantara du dan 4-du.

Tabel 6. Hasil Uji Autokolerasi

\begin{tabular}{|c|c|c|c|c|c|}
\hline \multicolumn{6}{|c|}{ Model Summary $^{\mathbf{b}}$} \\
\hline Model & $\mathrm{R}$ & R Square & $\begin{array}{c}\text { Adjusted R } \\
\text { Square }\end{array}$ & $\begin{array}{l}\text { Std. Error of } \\
\text { the Estimate }\end{array}$ & $\begin{array}{l}\text { Durbin- } \\
\text { Watson }\end{array}$ \\
\hline 1 & $.484^{\mathrm{a}}$ & .235 & .157 & .2431949 & 1.979 \\
\hline
\end{tabular}

Tabel 6 di atas menunjukkan bahwa nilai Durbin-Watson adalah sebesar 1,979 yang artinya dengan jumlah sampel (n) 66 (enam puluh enam) dan jumlah variabel $(\mathrm{k}=6) 6$ (enam), nilai (4-dU) yang diperoleh sebesar 2,1959 dan nilai dU sebesar 1,8041. Nilai Durbin Watson yang diperoleh terletak di antara dU (1,8041) dengan 4-dU (4-1,8041) yakni $1,8041<1,979<2,1959$ sehingga dapat disimpulkan bahwa model regresi yang digunakan dalam penelitian terbebas dari masalah autokolerasi dan layak digunakan.

Uji Heteroskesdastisitas. Ghozali (2011) menyatakan bahwa pengujian Heteroskedastisitas bertujuan untuk menguji apakah dalam sebuah model regresi terjadi ketidaksamaan varian dari satu pengamatan ke pengamatan lainnya. Model regresi yang baik adalah yang tidak terjadi heteroskedastisitas.Model regresi yang bebas dari masalah heteroskedastisitas dalam Uji Glejser dapat diketahui apabila nilai sig $>0.05$, kondisi sebaliknya jika sig $<0.05$ maka mengalami masalah heteroskedastisitas.

Tabel 7 menunjukkan bahwa nilai signifikansi return on asset sebesar 0,073. Nilai signifikansi debt to equity ratio sebesar 0,936. Nilai signifikansi earning per share sebesar 0,385. Nilai signifikansi umur perusahaan sebesar 0,269. Nilai signifikansi ukuran perusahaan sebesar 0,818. Nilai signifikansi penawaran saham ke publik 0,810. Berdasarkan uraian di atas, semua variabel yang digunakan memiliki nilai signifikansi lebih besar dari 0,05 sehingga dapat disimpulkan bahwa tidak ada gejala heteroskedastisitas dalam model regresi. 
Tabel 7. Hasil Uji Heteroskedastisitas

\begin{tabular}{|c|c|c|c|c|c|c|}
\hline \multicolumn{7}{|c|}{ Coefficients $^{\mathrm{a}}$} \\
\hline & & $\begin{array}{r}\text { Unstan } \\
\text { Coeff }\end{array}$ & $\begin{array}{l}\text { ardized } \\
\text { cients }\end{array}$ & $\begin{array}{l}\text { Standardized } \\
\text { Coefficients }\end{array}$ & & \\
\hline \multicolumn{2}{|l|}{ Model } & B & Std. Error & Beta & $\mathrm{T}$ & Sig. \\
\hline \multirow[t]{8}{*}{1} & (Constant) & .263 & .061 & & 4.317 & .000 \\
\hline & ROA & -.534 & .292 & -.238 & -1.829 & .073 \\
\hline & DER & -.001 & .012 & -.012 & -.081 & .936 \\
\hline & EPS & $-4.115 \mathrm{E}-6$ & .000 & -.111 & -.875 & .385 \\
\hline & Umur Perusahaan & -.002 & .002 & -.150 & -1.115 & .269 \\
\hline & Ukuran & $2.207 \mathrm{E}-15$ & .000 & .033 & .232 & .818 \\
\hline & Perusahaan & & & & & \\
\hline & $\begin{array}{l}\text { Penawaran Saham } \\
\text { ke Publik }\end{array}$ & -.039 & .163 & -.033 & -.241 & .810 \\
\hline
\end{tabular}

a. Dependent Variable: ABSRES

Hasil Pengujian Hipotesis. Analisis regresi berganda. Bedasarkan uji asumsi klasik yang telah dilakukan diperoleh kesimpulan bahwa data-data yang digunakan dalam penelitian ini telah memenuhi uji asumsi klasik.

Tabel 8. Hasil Uji Regresi Berganda

\begin{tabular}{|c|c|c|c|c|}
\hline \multicolumn{5}{|c|}{ Coefficients $^{a}$} \\
\hline \multirow{2}{*}{\multicolumn{2}{|c|}{ Model }} & \multicolumn{2}{|c|}{ Unstandardized Coefficients } & \multirow{2}{*}{$\begin{array}{l}\text { Standardized } \\
\text { Coefficients } \\
\text { Beta }\end{array}$} \\
\hline & & B & Std. Error & \\
\hline 1 & (Constant) & 411 & .118 & \\
\hline & ROA & -1.243 & .564 & -.262 \\
\hline & DER & -.041 & .024 & -.235 \\
\hline & EPS & $-4.790 \mathrm{E}-6$ & .000 & -.061 \\
\hline & Umur Perusahaan & .003 & .003 & .132 \\
\hline & Ukuran & $-3.708 \mathrm{E}-14$ & .000 & -.261 \\
\hline & Perusahaan & & & \\
\hline & $\begin{array}{l}\text { Penawaran Saham } \\
\text { ke Publik }\end{array}$ & .308 & .314 & .121 \\
\hline
\end{tabular}

a. Dependent Variable: Initial Return

Berdasarkan Tabel 8 model regresi dalam penelitian ini adalah sebagai berikut:

$$
\begin{aligned}
\mathrm{Y}= & 0,411-1,243 \mathrm{X}_{1}-0,041 \mathrm{X}_{2}-4,790 \mathrm{E}-6 \mathrm{X}_{3}+0,003 \mathrm{X}_{4}-3,708 \mathrm{E}-14 \mathrm{X}_{5}+ \\
& 0,308 \mathrm{X}_{6}+\mathrm{e}
\end{aligned}
$$

Keterangan: $\mathrm{Y}=$ Initial Return; $\mathrm{X}_{1}=$ Return on Asset $(\mathrm{ROA}) ; \mathrm{X}_{2}=$ Debt to Equity Ratio (DER); $\mathrm{X}_{3}=$ Earning per Share (EPS); $\mathrm{X}_{4}=$ Umur Perusahaan $($ Age $) ; \mathrm{X}_{5}=$ Ukuran Perusahaan $($ Size $) ; \mathrm{X}_{6}=$ Persentase Penawaran Saham Publik

Uji Signifikansi Regresi secara Simultan (Uji F). Uji F digunakan untuk menguji kelayakan model regresi berganda. Dasar pengambilan keputusan ini adalah apabila nilai signifikansi yang diperoleh dari tabel signifikan lebih kecil dari 0,05 (signifikansi < 0,05) 
dan maka model regresi layak digunakan. Sebaliknya, jika nilai signifikansi lebih besar atau sama dengan 0,05 (signifikansi > 0,05) maka model regresi tidak layak untuk digunakan.

Tabel 9. Hasil Uji F

\begin{tabular}{|c|c|c|c|c|c|c|}
\hline \multicolumn{7}{|c|}{ ANOVA $^{b}$} \\
\hline Model & & Sum of Squares & $\mathrm{df}$ & Mean Square & $\mathrm{F}$ & Sig. \\
\hline \multirow[t]{3}{*}{1} & Regression & 1.069 & 6 & .178 & 3.012 & $.012^{\mathrm{a}}$ \\
\hline & Residual & 3.489 & 59 & .059 & & \\
\hline & Total & 4.558 & 65 & & & \\
\hline
\end{tabular}

a. Predictors: (Constant), Penawaran Saham ke Publik , DER, EPS, ROA, Umur Perusahaan, Ukuran Perusahaan

b. Dependent Variable: Initial Return

Pada Tabel 9 hasil uji $\mathrm{F}$ menunjukkan nilai $\mathrm{F}$ hitung sebesar 3,012 dengan signifikansi 0,012. Nilai signifikansi dalam pengujian ini diperoleh lebih kecil dari 0,05 artinya dapat disimpulkan bahwa model regresi layak digunakan untuk memprediksi tingkat underpricing. Kondisi ini dapat dikatakan bahwa dari antara variabel return on asset, debt to equity ratio, earning per share, umur perusahaan, ukuran perusahaan serta persentase kepemilikan saham paling tidak ada satu variabel yang memengaruhi tingkat underpricing saham. Atau secara bersama-sama return on asset, debt to equity ratio, earning per share, umur perusahaan, ukuran perusahaan serta persentase kepemilikan saham berpengaruh terhadap tingkat underpricing saham.

Uji Signifikansi Regresi secara Parsial (Uji t). Uji t digunakan untuk menguji besarnya pengaruh variabel bebas terhadap variabel terikat. Pengujian dilakukan dengan menggunakan nilai signifikansi sebesar 0,05 . Hal itu dilakukan guna penentuan keputusan untuk menerima atau menolak hipotesis yang dirumuskan. Penelitian dilakukan dengan menggunakan tingkat signifikan 5\% $(\alpha=0,05)$. Kriteria pengujian uji t adalah jika nilai signifikansi lebih kecil dari 0,05 (signifikansi $\leq 0,05$ ), maka Ho ditolak dan Ha diterima dan jika nilai signifikan lebih besar dari 0,05 (signifikansi > 0,05), maka Ho diterima dan Ha ditolak.

Tabel 10. Hasil Uji t

Coefficients $^{\mathrm{a}}$

\begin{tabular}{|c|c|c|c|c|c|c|}
\hline \multirow[b]{2}{*}{ Model } & & \multicolumn{2}{|c|}{$\begin{array}{l}\text { Unstandardized } \\
\text { Coefficients }\end{array}$} & \multirow{2}{*}{$\begin{array}{l}\text { Standardized } \\
\text { Coefficients } \\
\text { Beta }\end{array}$} & \multirow[b]{2}{*}{$\mathrm{T}$} & \multirow[b]{2}{*}{ Sig. } \\
\hline & & B & Std. Error & & & \\
\hline \multirow[t]{7}{*}{1} & (Constant) & .411 & .118 & & 3.484 & .001 \\
\hline & ROA & -1.243 & .564 & -.262 & -2.202 & .032 \\
\hline & DER & -.041 & .024 & -.235 & -1.752 & .085 \\
\hline & EPS & $-4.790 \mathrm{E}-6$ & .000 & -.061 & -.527 & .600 \\
\hline & Umur Perusahaan & .003 & .003 & .132 & 1.070 & 289 \\
\hline & Ukuran Perusahaan & $-3.708 \mathrm{E}-14$ & .000 & -.261 & -2.014 & .049 \\
\hline & $\begin{array}{l}\text { Penawaran Saham } \\
\text { ke Publik }\end{array}$ & .308 & .314 & .121 & .980 & .331 \\
\hline
\end{tabular}

a. Dependent Variable: Initial Return 
Hasil uji t pada Tabel 10 menunjukkan nilai signifikan retun on asset adalah sebesar 0,032 dengan nilai t sebesar -2.202. Nilai signifikansi return on asset sebesar 0,032 ini lebih kecil dari 0,05 sehingga $\mathrm{Ha}_{1}$ yakni, return on asset memiliki pengaruh yang signifikan terhadap tingkat underpricing saham diterima. Variabel return on asset dinyatakan memiliki pengaruh yang signifikan terhadap tingkat underpricing. Hasil ini sesuai dengan penelitian Prastica (2012) bahwa return on asset memiliki pengaruh terhadap tingkat underpricing. Profitabilitas yang ditunjukkan oleh return on asset menunjukkan profit yang dihasilkan oleh perusahaan melalui pengelolaan asetnya. Semakin tinggi return on asset menunjukkan kemampuan perusahaan untuk menghasilkan laba yang lebih tinggi dengan memanfaatkan aset yang dimiliki. Profitabilitas yang tinggi akan menarik lebih banyak investor untuk melakukan investasi sehingga permintaan akan saham perusahaan meningkat, permintaan saham yang meningkat akan meninggikan harga saham. Jadi semakin tinggi return on asset perusahaan akan semakin rendah tingkat underpricing karena investor akan menilai kinerja perusahaan lebih baik dan bersedia membeli saham perdananya dengan harga yang lebih tinggi. Sehingga return on asset berpengaruh signifikan terhadap underpricing.

Hasil uji t terhadap debt to equity ratio pada Tabel 10 memiliki nilai signifikansi sebesar 0,085 dengan nilai t sebesar -1,752. Nilai signifikansi debt to equity ratio sebesar 0,085 ini lebih besar dari 0,05 sehingga memberikan kesimpulan $\mathrm{Ha}_{2}$ yakni debt to equity ratio memiliki pengaruh yang signifikan terhadap tingkat underpricing saham ditolak. Hal ini berarti debt to equity ratio tidak memiliki pengaruh yang signifikan terhadap tingkat underpricing. Hasil ini sesuai dengan penelitian yang dilakukan oleh Retnowati (2013) bahwa debt to equity ratio tidak berpengaruh terhadap tingkat underpricing saham. Alasan debt to equity ratio tidak berpengaruh terhadap underpricing adalah karena debt to equity ratio menunjukkan rasio hutang ini lebih mencerminkan risiko perusahaan yang relatif tinggi sehingga mengakibatkan ketidakpastian harga saham dan berdampak pada return saham yang nantinya akan diterima oleh investor akibatnya investor cenderung untuk menghindari saham perusahaan yang memiliki debt to equity ratio yang tinggi.

Hipotesis ketiga dalam penelitian ini adalah $\mathrm{Ha}_{3}$ yakni earning per share memiliki pengaruh yang signifikan terhadap tingkat underpricing saham. Pada tabel 4.10. earning per share memiliki signifikansi sebesar 0,600 dengan nilai t sebesar -0,527. Nilai signifikansi sebesar 0,600 lebih besar dari 0,05, hal ini berarti $\mathrm{Ha}_{3}$ ditolak earning per share tidak memiliki pengaruh yang signifikan terhadap tingkat underpricing saham. Hasil ini sesuai dengan penelitian yang dilakukan oleh Astuti dan Syahyunan (2012). Dikatakan bahwa earning per share tidak berpengaruh signifikan terhadap tingkat underpricing saham. Earning per share dinilai tidak konsisten untuk pengukuran profitabilitas karena memakai laba perusahaan yang dibagi (numerator) dengan memakai jumlah saham pada pembagi (denominator) yang merupakan hasil keputusan pendanaan. Oleh karena itu investor mungkin kurang memperhatikan nilai earning per share untuk keputusan investasi.

Hasil uji t pada tabel 4.10. menyatakan bahwa umur perusahaan memiliki tingkat signifikansi sebesar 0,289 dengan nilai t sebesar 1,070. Nilai signifikansi umur perusahaan sebesar 0,289 ini lebih besar dari 0,05 sehingga memberikan kesimpulan $\mathrm{Ha}_{4}$ yakni, umur perusahaan memiliki pengaruh yang signifikan terhadap tingkat underpricing saham ditolak. Hal ini berarti umur perusahaan tidak memiliki pengaruh yang signifikan terhadap tingkat underpricing. Hasil ini sesuai dengan penelitian Retnowati (2013) bahwa umur perusahaan tidak berpengaruh signifikan terhadap tingkat underpricing. Investor tidak 
mempertimbangkan umur perusahaan dalam menilai emiten yang melakukan initial public offering. Dunia bisnis yang identik dengan persaingan, belum tentu perusahaan yang lebih muda mempunyai kinerja atau prospek yang tidak lebih baik dibandingkan dengan perusahaan-perusahaan yang telah lama berdiri. Umur suatu perusahaan tidak selalu menjamin bahwa perusahaan tersebut merupakan perusahaan yang memiliki kondisi keuangan yang sehat, sebab perusahaan baik yang telah lama atau baru berdiri dapat mengalami kondisi keuangan yang tidak sehat atau bahkan kebangkrutan.

Hasil uji t terhadap ukuran perusahaan pada tabel 4.10. memiliki nilai signifikansi sebesar 0,049 dengan nilai t sebesar -2,014. Nilai signifikansi ukuran perusahaan sebesar 0,049 ini lebih besar dari 0,05 sehingga memberikan kesimpulan Ha yakni, ukuran perusahaan memiliki pengaruh yang signifikan terhadap tingkat underpricing saham diterima. Hal ini berarti ukuran perusahaan memiliki pengaruh yang signifikan terhadap tingkat underpricing. Hasil ini sesuai dengan penelitian yang dilakukan oleh Retnowati (2013). Pertimbangan bahwa ukuran perusahaan yang besar umumnya lebih dikenal, maka informasi mengenai perusahaan besar lebih banyak dibanding perusahaan yang relatif kecil. Informasi yang memadai akan bisa mengurangi tingkat ketidakpastian investor akan prospek perusahaan ke depan. Secara teoritis, perusahaan yang lebih besar memiliki kepastian (certainty) yang lebih tinggi atau tingkat uncertainty yang rendah, pada umumnya hasil regresinya memiliki kecenderungan tingkat underpricing yang rendah pula, karena investor dapat memprediksi risiko yang dihadapinya jika melakukan investasi dalam saham perusahaan emiten.

Hipotesis keenam dalam penelitian ini adalah terkait dengan variabel persentase penawaran saham ke publik. Tabel 10 persentase penawaran saham memiliki signifikansi sebesar 0,331 dengan nilai t sebesar 0,980. Nilai signifikansi sebesar 0,331 lebih besar dari 0,05, hal ini berarti $\mathrm{Ha}_{6}$ yakni, persentase penawaran saham ke publik memiliki pengaruh yang signifikan terhadap tingkat underpricing saham ditolak persentase penawaran saham dianggap tidak memiliki pengaruh yang signifikan terhadap tingkat underpricing saham. Hal ini sejalan dengan penelitian yang dilakukan oleh Yustisia dan Roza (2012) dan Wulandari serta Haryanto (2011). Pembelian saham yang ditawarkan ke publik, bukan berpatokan pada jumlah lembar yang ditawarkan tetapi pada besar nilai penawaran tersebut, karena harga saham akan menentukan besar kecilnya keuntungan. Semakin rendah harga yang ditawarkan, semakin tinggi keinginan investor untuk membeli saham tersebut, yang berpengaruh terhadap tingkat underpricing yang semakin tinggi juga. Alasan lain tidak berpengaruhnya memungkinkan besar kecilnya persentase penawaran saham ke publik tidak berarti, apakah perusahaan yang bersangkutan mempunyai kredibilitas yang baik atau tidak di mata publik.

Uji Coefficient Multiple Determination $\left(\mathbf{R}^{2}\right)$. Uji koefisien determinasi ganda (Adjusted $R$ Square) bertujuan untuk mengetahui seberapa besar variasi dari variabel bebas, dapat menjelaskan variabel terikat.

Tabel 11. Hasil Uji Koefisien Determinasi Ganda

\begin{tabular}{lrrrrr}
\hline \multicolumn{5}{c}{ Model Summary } \\
Model & $\mathrm{R}$ & \multicolumn{2}{c}{$\begin{array}{c}\text { Adjusted } \\
\text { R Std. Error of the } \\
\text { Estimate }\end{array}$} \\
\hline 1 & $.484^{\mathrm{a}}$ & .235 & .157 & .2431949
\end{tabular}

a. Predictors: (Constant), Penawaran Saham ke Publik, DER, EPS, ROA, Umur Perusahaan, Ukuran Perusahaan 
Pada Tabel 11 nilai Adjusted $R$ Square sebesar 0,157. Angka ini menunjukkan bahwa sebesar $15,7 \%$ tingkat underpricing saham dapat dijelaskan oleh return on asset, debt to equity ratio, earning per share, umur perusahaan, ukuran perusahaan, dan persentase penawaran saham publik sedangkan sisanya sebesar $84,3 \%$ dijelaskan oleh variabel lain di luar penelitian ini.

\section{PENUTUP}

Tujuan dari penelitian ini adalah untuk meneliti pengaruh return on asset, debt to equity ratio, earning per share, umur perusahaan (age), ukuran perusahaan (size), dan persentase penawaran saham terhadap tingkat underpricing saham yang terdaftar di Bursa Efek Indonesia. Penelitian dilakukan dengan menggunakan 66 (enam puluh enam) sampel perusahaan yang melakukan initial public offering periode 2007-2012. Berdasarkan hasil penelitian yang telah dilakukan dengan melalui tahap pengumpulan dan pengolahan data, tahap analisis dan interpretasi hasil mengenai hubungan variabel independen dengan variabel dependen yang dipilih, maka dapat ditarik beberapa kesimpulan untuk menjawab permasalahan dari penelitian ini. Pertama, return on asset memiliki pengaruh yang signifikan berpengaruh terhadap tingkat underpricing saham perdana. Kedua, debt to equity ratio tidak memiliki pengaruh yang signifikan terhadap tingkat underpricing saham perdana. Rasio pengembalian hutang oleh ekuitas tidak menjadi patokan dalam penentuan harga saham. Ketiga, Earning per Share tidak memiliki pengaruh yang signifikan terhadap tingkat underpricing saham perdana. Keempat, umur perusahaan tidak memiliki pengaruh yang signifikan terhadap tingkat underpricing saham perdana. Kelima, ukuran perusahaan memiliki pengaruh yang signifikan terhadap tingkat underpricing saham perdana. Keenam, persentase penawaran saham ke publik tidak memiliki pengaruh yang signifikan terhadap tingkat underpricing saham perdana.

Besarnya kontribusi yang diberikan return on asset, debt to equity ratio, earning per share, umur perusahaan (age), ukuran perusahaan (size), dan persentase penawaran saham terhadap tingkat underpricing saham dapat dilihat dari nilai adjusted $\mathrm{R}^{2}$ sebesar 0,157 atau $15,7 \%$. Hal ini berarti $15,7 \%$, variabel tingkat underpricing saham dapat dijelaskan oleh variasi dari variabel return on asset, debt to equity ratio, earning per share, umur perusahaan (age), ukuran perusahaan (size), dan persentase penawaran saham sedangkan sisanya sebesar 84,3\% dijelaskan oleh variabel-variabel lain di luar model penelitian.

Berdasarkan kesimpulan dari analisis dan pembahasan terhadap masalah penelitian, maka terdapat beberapa saran yang dapat diberikan. Bagi para calon emiten yang akan melakukan initial public offering dapat diberikan saran bahwa sebelum melakukan initial public offering, hendaknya secara matang mempertimbangkan segala aspek yang akan menentukan harga sebuah saham yang akan diterbitkan diantaranya return on asset dan ukuran perusahaan (size). Return on asset menjadi parameter pengukuran profitabilitas suatu perusahaan dalam mengoperasikan aset yang dimiliki untuk menghasilkan keuntungan. Ukuran perusahaan (size) dalam penelitian ini menjadi pandangan yang sangat menarik bagi investor dalam melakukan pertimbangan investasinya. Kedua hal tersebut dalam penelitian ini menjadi salah satu faktor yang berpengaruh siginifikan terhadap tingkat underpricing. Bagi investor juga dapat diberikan saran bahwa hendaknya mempertimbangkan informasi yang terdapat dalam prospektus terutama mengenai informasi return on asset yang sesuai dengan hasil penelitian ini berpengaruh terhadap underpricing. 
Bagi peneliti selanjutnya, penelitian ini masih jauh dari sempurna karena memiliki beberapa keterbatasan. Oleh karena itu untuk kesempurnaan penelitian yang akan datang bagi para peneliti yang tertarik untuk melakukan penelitian yang sama, sebaiknya menambah jumlah sampel dengan cara memperpanjang periode pengamatan. Penelitian selanjutnya juga dapat menggunakan variabel-variabel lain yang dapat diperkirakan akan berpengaruh terhadap tingkat underpricing saham, seperti return on equity, price earning ratio, jenis perusahaan, reputasi underwriter, maupun reputasi auditor untuk faktor mikronya, untuk faktor makronya disertakan variabel inflasi, indeks harga saham dan variabel lainnya.

\section{DAFTAR RUJUKAN}

Aritonang, Lerbin R. (2007) Riset Pemasaran Teori dan Praktek. Bogor: Ghalia

Arman, Agus. (2012) Pengaruh umur dan ukuran perusahaan, reputasi underwriter dan return on equity terhadap tingkat underpricing saham di Bursa Efek Indonesia. Universitas Kristen Satya Wacana

Astuti, Asih Yuli dan Syahyunan. (2013) Pengaruh variabel keuangan dan non keuangan terhadap underpricing pada saham perusahaan yang melakukan Initial Public Offering di Bursa Efek Indonesia. Universitas Sumatera Utara

Darmadji, Tjiptono dan Hendi M. Fakhrudin. (2006) Pasar modal di Indonesia Pendekatan Tanya Jawab. Edisi Kedua. Jakarta: Salemba Empat

Gibson, Charles H. (2013) Financial reporting and analysis: using financial accounting information. $14^{\text {th }} \mathrm{ed}$. United States: South-Western Cengage Learning

Handayani, Sri Retno dan Shaferi, Intan. (2011) Analisis faktor-faktor yang mempengaruhi underpricing pada penawaran umum perdana (studi kasus pada perusahaan yang go publik di Bursa Efek Jakarta Tahun 2000-2006. Performance. Vol. 14. No. 2

Ikatan Akuntan Indonesia. (2009) Standard Akuntansi Keuangan. Jakarta: Salemba Empat

Indirawati, Novita. (2005) Analisis faktor-faktor yang mempengaruhi underpricing pada penawaran umum perdana. Jurnal Akuntansi dan Bisnis. Vol.1

Khomsiyah. (2005) Reputasi penjamin emisi, reputasi auditor dan tingkat underpricing pada penawaran perdana di Bursa Efek Jakarta. Jurnal Bisnis dan Akuntansi. Vol.7. No. 2

Kristiantari, I Dewa Ayu. (2013) Analisis faktor-faktor yang mempengaruhi underpricing saham pada penawaran saham perdana di Bursa Efek Indonesia. Jurnal Ilmiah Akuntansi Humanika. Vol. 2. No. 2

Prastica, Yurena. (2012) Faktor-Faktor yang mempengaruhi tingkat underpricing pada saat penawaran umum saham perdana. Jurnal Ilmiah Mahasiswa Akuntansi. Vol. 1. No. 2

Retnowati, Eka. (2013) Penyebab underpricing pada penawaran saham perdana di Indonesia. Accounting Anlysis Journal. Vol.1. No. 4

Saunders, Anthony dan Cornett, Marcia Millon. (2003) Financial markets and institutions, International edition. $2^{\text {nd }}$ ed. United States Of America: Mc Graw Hill

Sunariyah. (2006) Pengantar pengetahuan pasar modal. Edisi Kelima. Yogyakarta: UPP STIM YKPN

Witjaksono, Lydia Soeryadjaya. (2012) Analisis faktor-faktor keuangan yang mempengaruhi fenomena underpricing pada perusahaan sektor keuangan yang 
terdaftar di Bursa Efek Indonesia 2002-2010. Berkala Ilmiah Mahasiswa Akuntansi. Vol. 1. No. 1

Wulandari, Afifah dan Haryanto Mulyo. (2011) Analisis faktor-faktor yang mempengaruhi underpricing pada penawaran umum perdana (IPO). http://eprints.undip.ac.id/28957/1/afifahwulandari_jurnal.pdf

Yustisia, Natali dan Roza, Mailana. (2012) Faktor-Faktor yang memengaruhi tingkat underpricing saham perdana pada perusahaan non-keuangan go public. Media Riset Akuntansi. Vol.2. No. 2 